\title{
Neonatal Deprivation of Maternal Touch May Suppress Ornithine Decarboxylase via Downregulation of the Proto-oncogenes c-myc and max
}

\author{
Shiying Wang, Jorge V. Bartolome, and Saul M. Schanberg \\ Department of Pharmacology, Duke University, Durham, North Carolina 27710
}

Previously, we have shown that short-term (1 hr) separation of neonatal rats from their mother (MS) suppresses basal ornithine decarboxylase $(O D C)$ synthesis and tissue $O D C$ response to trophic factors. This effect in the pup is caused by absence of maternal tactile stimulation (touch) but nol from lack of maternal nutrients (food). This study was performed to examine in 10-d-old rats whether maternal touch deprivation affects expression of certain hepatic proto-oncogenes, the protein products of which are known to interact with the regulatory region of the ODC gene. Prolactin (PRL) injected subcutaneously increased hepatic ODC activity as well as mRNA levels of $O D C$ and the proto-oncogenes c-fos, c-jun, junB, junD, c-myc, and max. MS significantly suppressed PRL-induced increases in $O D C$ enzyme activity and c-myc, max, and ODC mRNAs but had little effect on expression of the other proto-oncogenes. PRL-induced stimulation of $O D C, \mathrm{c}-m y c$, and max mRNAs also was depressed in neonates placed with an anesthetized lactating dam (touch-deprived) but not in pups placed with nippleligated dams (food-deprived). Furthermore, unlike its effect on preweanling-age pups ( $<20 \mathrm{~d}$ old), MS did not alter expression of either $O D C$ or c-myc mRNAs in 25-d-old pups acutely separated from their mother. These findings indicate that suppression of $O D C$ gene transcription in the neonatal pup during MS may be mediated by downregulation of the $O D C$ gene transactivator proto-oncogenes c-myc and max. They are also consistent with our previous observation that lack of maternal touch, but not maternal milk, initiates the physiological alterations induced by MS.

Key words: maternal separation; ornithine decarboxylase; c-myc; max; immediate-early genes; development; rat pup; maternal touch
Although development in mammals is affected profoundly by environmental stimuli, those provided by the mother are most critical for survival and growth. Evidence from this and other laboratories has documented that separation of young mammals from their mothers (MS) elicits very specific physiological and behavioral responses that can affect their development markedly. The maturational deficits resulting from prolonged MS are attributable to a variety of functional changes in hypothalamic-pituitary-adrenal, neuroendocrine, and metabolic systems and their altered response to environmental stimuli (Harlow and Zimmerman, 1959; Powell et al., 1967, 1973; Hinde and Spencer-Booth, 1971; Frasier and Rallison, 1972; Hofer, 1981).

We have demonstrated that short-term (1 hr) MS produces a decrease in the basal activity of ornithine decarboxylase $(O D C$; EC 4.1.1.17) and a suppression of tissue $O D C$ response to trophic stimuli in major tissues (Butler and Schanberg, 1977; Butler et al., 1978; Kuhn et al., 1979; Schanberg and Kuhn, 1985). ODC is the first and rate-limiting enzyme in the biosynthesis of the polyamines putrescine, spermidine, and spermine, molecules that are necessary for normal growth of both prokaryotic and eukaryotic organisms (Heby, 1981; Slotkin and Bartolome, 1986; Marton and Morris, 1987). This adaptive pattern of $O D C$ synthesis to MS is not related to food deprivation or body temperature changes; it is caused by the lack of a specific type of tactile stimulation of the pup by the mother, and it occurs only during the first threc

\footnotetext{
Received Aug. 2, 1995; revised Sept. 22, 1995; accepted Oct. 16, 1995.

This work was supported by NIH Grants MH13688 to S.M.S. and NS25738 to J.V.B.

Correspondence should be addressed to Dr. S. M. Schanberg, Department of Pharmacology, Duke University, P.O. Box 3813, Durham, NC 27710.

Copyright (C) 1996 Society for Neuroscience $0270-6474 / 96 / 160836-07 \$ 05.00 / 0$
}

postnatal weeks (Butler and Schanberg, 1977, 1978; Kuhn et al., 1978, 1979; Evoniuk et al., 1979; Pauk et al., 1986). Tactile stimulation in the form of firm stroking with a brush at a frequency that mimics maternal licking patterns reliably prevents or reverses the effects of MS on ODC (Evoniuk et al., 1979; Kuhn et al., 1979; Schanberg and Kuhn, 1980; Pauk et al., 1986).

An important issue arising from our studies concerns the intracellular mechanisms by which the regulation of tissue $O D C$ expression in the developing neonate is influenced by maternal tactile stimulation. Recent studics of proto-oncogene involvement in cell signal transduction pathways have elucidated some of the basic molecular mechanisms mediating hormonal regulation of $O D C$ gene transcription. Among the multiple intracellular responses associated with receptor activation, one of the earliest nuclear events is the increased expression of the proto-oncogenes c-fos and c-jun, also known as immediate-early genes (IEGs) (Herschman, 1989; Bravo, 1990). Fos and Jun, the proteins encoded by c-fos and c-jun mRNAs, respectively, interact to form heterodimeric complexes that function as transcriptional regulators of target genes. More importantly, Myc and Max, the proteins encoded by the proto-oncogenes c-myc and max have been shown in particular to participate in the normal regulation of both $O D C$ mRNA expression and cell development (Cole, 1986; Lüscher and Eisenman, 1990; Spencer and Groudine, 1991; Wagner et al., 1992, 1993; Bello-Fernandez et al., 1993; Peña et al., 1993).

The above findings are consistent with the hypothesis that MS suppresses $O D C$ gene expression in vivo by downregulating the transcription of proto-oncogenes such as c-myc/max and/or c-fos/ c-jun. To test this hypothesis, the present studies were designed to measure the effects of MS both on basal levels of hepatic c-fos, c-jun, junB, junD, c-myc, max, and $O D C$ mRNAs and on prolactin (PRL)-stimulated synthesis of these gene transcripts. PRL is a 
potent hepatotrophic hormone known to produce a dosedependent increase in levels of c-myc and $O D C$ mRNAs (Crowe et al., 1991), and the ability of PRL to increase $O D C$ enzyme activity in neonates is suppressed markedly by MS (Schanberg et al., 1984).

\section{MATERIALS AND METHODS}

Animal treatments. Rat pups in these studies were $10 \mathrm{~d}$ old, except for one experiment in which they were $25 \mathrm{~d}$ old. Lactating Sprague-Dawley rats with 5- or 20-d-old litters (10 pups/litter; Charles River Laboratories, Raleigh, NC) were randomized on arrival (to eliminate genetic influences), housed for $5 \mathrm{~d}$ in a vivarium maintained at $22^{\circ} \mathrm{C}$ with a $12 \mathrm{hr}$ light/dark cycle, and provided food (Purina Lab Chow, Ralston-Purina, St. Louis, MO) and water ad libitum. To reduce stress caused by a novel environment, animals were moved from the vivarium to the experimental room on the evening before experimentation. To lessen maternal caretaking differences further, pups from all litters were randomized and redistributed to the nursing mothers or MS groups on the day of the experiment. In addition, each dam or MS group included an animal from every experimental category. Animals were killed at about the same time of the day to minimize variations in circadian influences.

Maternal tactile and food deprivation studies. Nipples of dams from 10-d-old litters were ligated (under light ether anesthesia), and dams were allowed to recover for $3 \mathrm{hr}$. Pups from all dams were randomized and distributed to a lactating dam (control group), a nipple-ligated dam (pups deprived of food but not maternal care), a dam anesthetized with $1.2 \mathrm{mg}$ of urethane $/ \mathrm{kg}$ body weight (pups deprived of active maternal care but not food), or they were placed without a dam in a plastic cage maintained at $25^{\circ} \mathrm{C}$ (deprived of maternal care and food). Urethane anesthesia does not interfere with milk ejection or suckling in rat pups (Lincoln et al., 1973). Two hours later, pups from each group were injected with PRL $(20 \mathrm{mg} / \mathrm{kg}$ in $1 \mu \mathrm{l} / \mathrm{gm}$ body weight, i.p.; Sigma, St. Louis, MO) or with saline and killed by decapitation 0.5 or $2 \mathrm{hr}$ later. Livers were dissected, weighed, and processed for RNA analysis.

RNA isolation and Northern blot analysis. Total RNA was extracted from fresh livers with acid guanidinium thiocyanate-phenol-chloroform according to Chomczynski and Sacchi (1987) and enriched for polyA ${ }^{+}$containing RNA by Oligotex-dT chromatography (Qiagen, Chatsworth, CA) as reported previously (Bartolome et al., 1995). In brief, the polyadenylated RNA samples $(5.0-7.5 \mu \mathrm{g} /$ well $)$ were denaturated with $6 \% p$-formaldehyde and $50 \%$ formamide, fractionated by electrophoresis on $1.0 \%$ agarose $/ 2.2 \mathrm{M}$ formaldehyde gels (Lehrach et al., 1977), and transferred to a nitrocellulose membrane (Schleicher \& Schuell, Keene, NH) by capillary blotting. The RNA then was linked to the membrane by baking at $80^{\circ} \mathrm{C}$ for $1 \mathrm{hr}$. Membranes were incubated overnight at $42^{\circ} \mathrm{C}$ in a prehybridization solution containing $6 \times \mathrm{SSPE}$, $5 \times$ Denhardt's solution, $0.1 \%$ SDS, $50 \%$ formamide, $1.0 \mathrm{~mm}$ EDTA, and $100 \mu \mathrm{g} / \mathrm{ml}$ denatured salmon sperm DNA. To each milliliter of prehybridization solution was added $1 \times 10^{6} \mathrm{cpm}$ of heat-denaturated ${ }^{32} \mathrm{P}$-labeled DNA probe, and hybridization was carried out overnight at $42^{\circ} \mathrm{C}$. The membranes were washed twice with $2 \times$ SSC and $0.1 \%$ SDS at room temperature for $15 \mathrm{~min}$ each, once with $0.1 \times \mathrm{SSC}$ and $0.1 \%$ SDS at $42^{\circ} \mathrm{C}$ for $30 \mathrm{~min}$, and then with this same solution for $5-10 \mathrm{~min}$ at $65^{\circ} \mathrm{C}$. The membranes then were exposed to Kodak X-OMAT AR film for $3-5 \mathrm{~d}$ at $-70^{\circ} \mathrm{C}$ using an intensifying screen. Exposure time was adjusted to produce images within the linear response range of the film. Intensity of the hybridization signals was determined by laser densitometric scanning of autoradiograms using a Scanmaster $3+$ scanner (Howtek, Hudson, NH) and National Institutes of Health Image software (version 1.4). To correct for differences in potential RNA loading, the absorbance values for individual blots were normalized using the absorbance values of the corresponding blot probed with glyceraldehyde-3-phosphate dehydrogenase (GAPDH) cDNA on the same filter (Sabath et al., 1990). Each set of experiments was replicated to verify reproducibility of results.

Probes. DNA probes used in this study were as follows. A $2.2 \mathrm{~kb}$ Eco RI fragment of mouse $O D C$ (Wen et al., 1989) was provided by Dr. P. Blackshear (Duke University, Durham, NC). A 4.8 kb XbaI-BamHI fragment of mouse c-myc gene containing the second and third exons (Land et al., 1983) was provided by Dr. R. Weinberg (MIT, Cambridge, MA). A $0.55 \mathrm{~kb} E c o$ RI fragment of human $\max$ (Blackwood and Eisenman, 1991) was provided by Dr. R. Eisenman (Fred Hutchinson Cancer Research Center, Seattle, WA). A $2.2 \mathrm{~kb}$ EcoRI fragment of rat c-fos (Curran et al., 1987) was provided by Dr. T. Curran (Roche Institute for
A

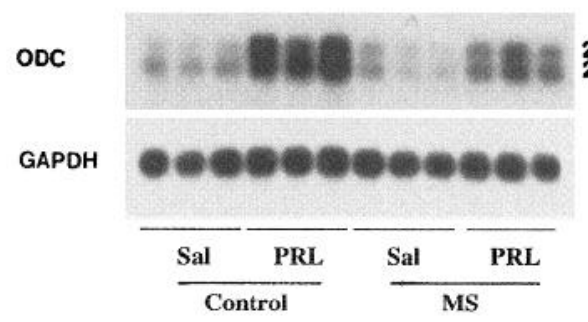

B

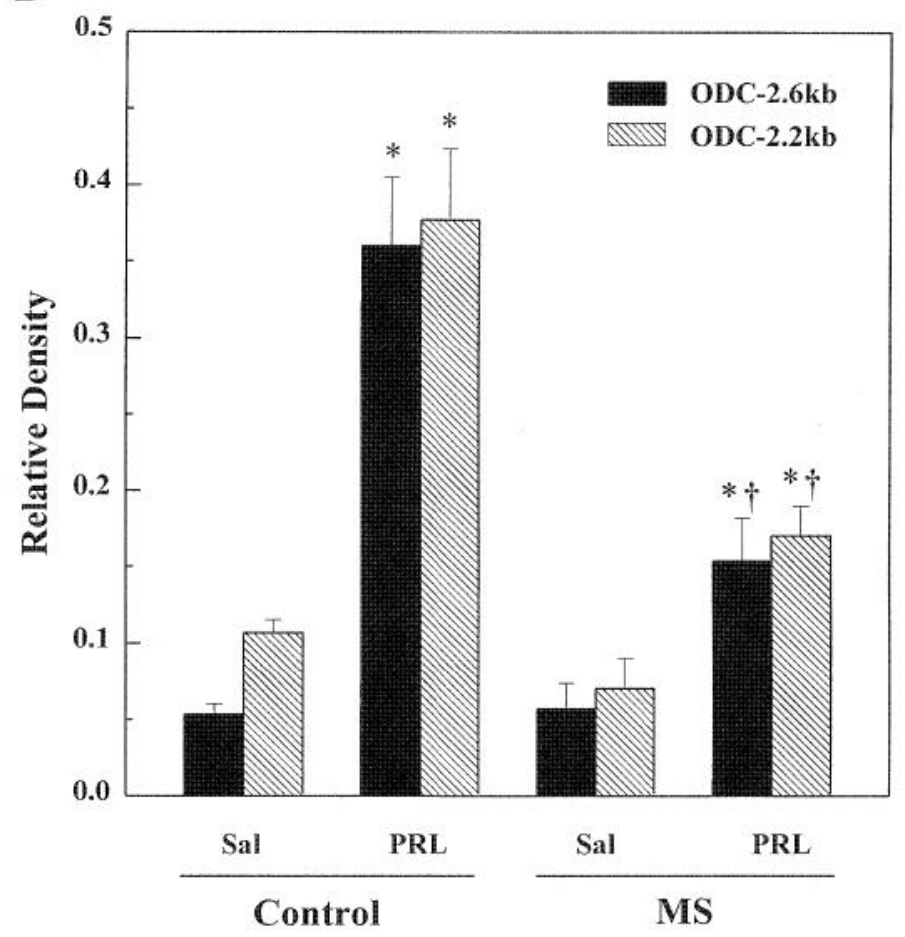

Figure 1. A, Effect of MS on PRL-induced expression of hepatic $O D C$ mRNA in 10-d-old rats. Pups were separated from their dams for $2 \mathrm{hr}$, injected intraperitoneally with $P R L$ or saline (Sal), and killed $2 \mathrm{hr}$ after injection. Littermate control pups were left with their dams, injected intraperitoneally with PRL or saline, and killed $2 \mathrm{hr}$ after injection. PolyA $^{+}$RNA was isolated and subjected to Northern analysis. GAPDH cDNA was used to demonstrate equal loading of RNA samples. Each blot is the result obtained from one pup. $B$, Densitometric analysis of the autoradiogram shown in $A$. $p \leq 0.05$ versus respective saline $(\mathrm{Sal})\left(^{*}\right)$ or control PRL (†) group.

Molecular Biology, Nutley, NJ).- A 1.9 kb BamHI fragment of c-jun (Lamph et al., 1988) was provided by Dr. I. Verma (The Salk Institute, La Jolla, CA). A $1.3 \mathrm{~kb}$ EcoRI fragment of mouse GAPDH (Sabath et al., 1990) was provided by Dr. M. Prystowsky (University of Pennsylvania, Philadelphia, PA). A $1.5 \mathrm{~kb}$ EcoRI fragment of mouse junB [American Type Culture Collection (ATCC; number 63025)] and a $1.7 \mathrm{~kb}$ EcoRI fragment of mouse junD (ATCC number 63024) both were purchased from ATCC (Rockville, MD). All probes were radiolabeled with $\left[\alpha{ }^{32} \mathrm{P}\right] \mathrm{dCTP}(3000 \mathrm{Ci} / \mathrm{mmol}$; DuPont NEN, Boston, MA) to a specific activity of $1-2 \times 10^{6} \mathrm{cpm} / \mu \mathrm{g}$ using a random-primed DNA-labeling kit from Boehringer Mannheim (Indianapolis, IN). NucTrap push columns (Stratagene, La Jolla, CA) were used for separating unincorporated nucleotides from radiolabeled DNA probes. All reagents were of analytical grade.

Statistics. For statistical comparisons, we used one- or two-way ANOVA, followed by post hoc analyses (Student-Newman-Keuls or 
A

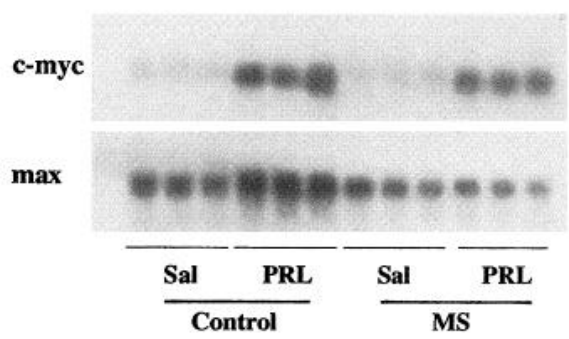

Figure 2. A, Effect of MS on PRL-induced expression of hepatic c-myc and $\max$ mRNAs in 10-d-old rats. PolyA ${ }^{+}$RNA was isolated from tissue obtained from the same pups described in Figure $1 A$. Each blot is the result obtained from one pup. $B$, Densitometric analysis of the autoradiogram shown in $A$. Results are expressed as mean \pm SEM. $p \leq 0.05$ versus respective saline $(\mathrm{Sal})\left(^{*}\right)$ or control PRL $(\dagger)$ group. Designations as in Figure 1.

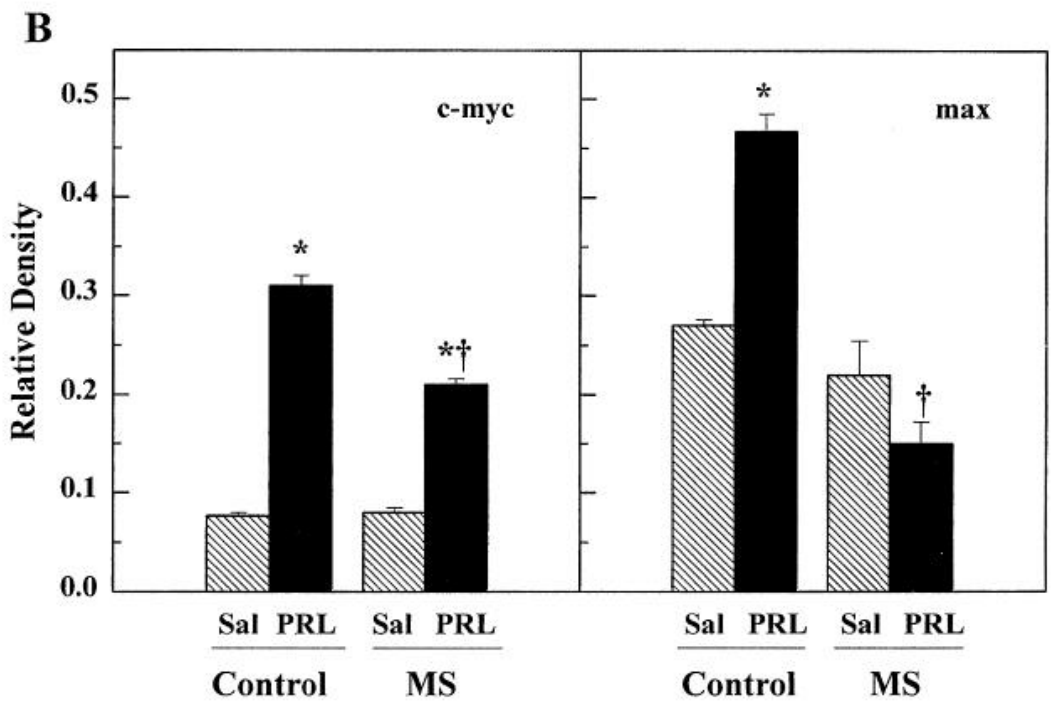

Dunn's method, where appropriate). Statistical significance was accepted at $p \leq 0.05$.

\section{RESULTS}

\section{Effect of MS on PRL-induced expression of hepatic $O D C$, c-myc, and max mRNAs in 10-d-old pups}

Control or MS ( $2 \mathrm{hr})$ pups were injected with PRL, and mRNAs were analyzed $2 \mathrm{hr}$ later. Two-way ANOVA indicated a significant overall increase in mRNAs by PRL and a significant interaction of PRL $\times$ MS. As shown in Figure 1, $A$ (a representative Northern hybridization autoradiogram) and $B$ (the densitometric analysis of the autoradiogram), PRL increased $O D C$ mRNA expression in both control $(O D C-2.6 k b, p<0.001 ; O D C-2.2 k b, p<0.001)$ and MS (ODC-2.6 kb, $p<0.01 ; O D C-2.2 k b, p<0.005)$ animals. However, the amount of mRNA expressed in MS pups was markedly less than in control pups $(O D C-2.6 \mathrm{~kb}, p<0.01 ; O D C$ $2.2 k b, p<0.03$ ). Similarly, although PRL increased transcription of the proto-oncogenes c-myc $(p<0.0001)$ and $\max (p<0.02)$ in control pups (Fig. 2A,B), the effect was suppressed significantly by MS (c-myc, $p<0.01 ; \max , p<0.001)$. MS did not alter basal mRNA levels significantly.

\section{Effect of MS on PRL-induced expression of c-fos and jun family mRNAs}

As can be seen in Figure 3, $A$ and $B$, basal levels of hepatic c-fos and jun family mRNAs were barely detectable in control animals. Although PRL administration markedly enhanced the expression of the IEGs c-fos, c-jun, junB, and junD as indicated by overall two-way ANOVA, only the induction of c-fos tended to be re- duced (12\%) by MS interaction. Also, data analysis for individual pups showed no significant relationship between a decrease in c-fos mRNA and a decrease in $O D C$ mRNA levels.

\section{Effect of touch deprivation versus food deprivation on PRL-induced ODC, c-myc, and max mRNA transcription}

To determine whether the suppression of $O D C$, c-myc, and max gene expression by MS is caused by loss of maternal touch, food, or both, pups were placed with lactating mothers that were untreated (control), anesthetized [no maternal touch but normal milk supply (Lincoln et al., 1973)], or nipple-ligated [no milk supply but normal maternal touch (Kuhn et al., 1979; Schanberg et al., 1984)]. After $2 \mathrm{hr}$, all pups were injected with PRL and killed $2 \mathrm{hr}$ later. As indicated in Figure 4, $O D C$ mRNA induction by PRL was reduced significantly in pups placed with anesthetized mothers (one-way ANOVA; $p<0.01$ ) but was not affected in pups placed with nipple-ligated dams. Similarly, induction of c-myc and max mRNAs by PRL also was suppressed significantly in pups placed with the anesthetized dams (one-way ANOVA; $p$ $<0.001$ and 0.003 , respectively) but not in pups placed with nipple-ligated dams (Fig. 5).

\section{Effect of MS on PRL-induced hepatic ODC and c-myc mRNAs in 25-d-old pups}

MS only suppresses $O D C$ enzyme induction by growth hormone $(\mathrm{GH})$, insulin, and PRL in preweanling pups (Butler and Schanberg, 1977; Bartolome et al., 1991). To characterize further the role of c-myc in this age-limited process, pups were kept with their 
A

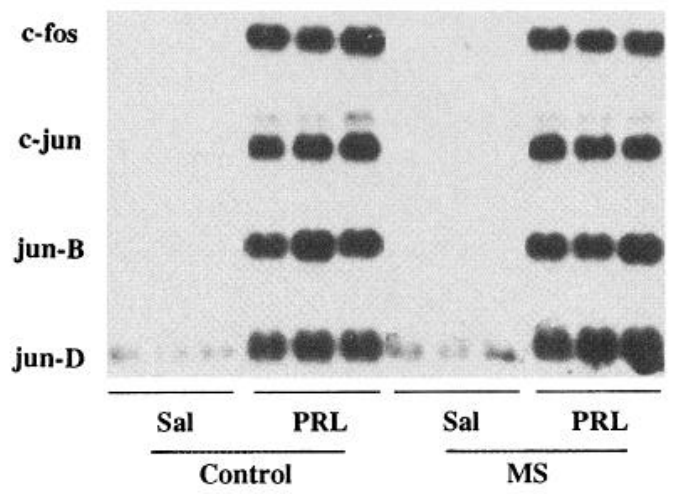

B

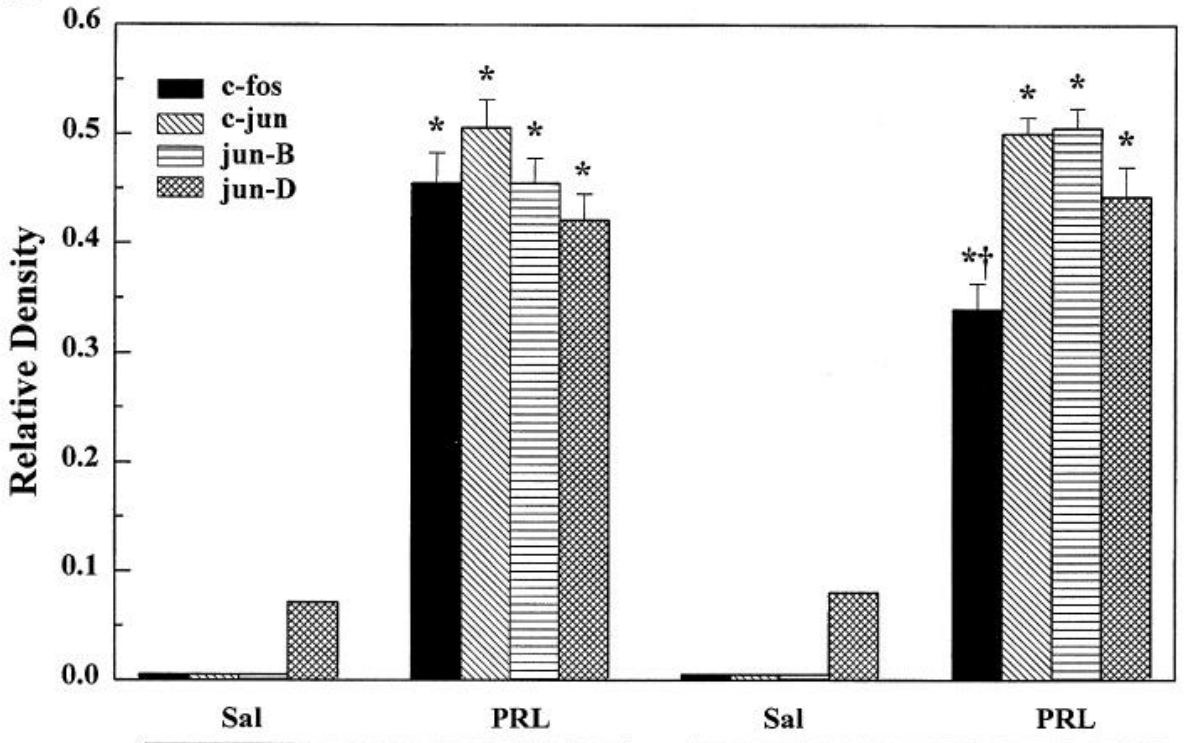

Control

MS
Figure 3. A, Effect of MS on PRL-induced expression of c-fos, c-jun, jun-B, and jun-D mRNAs in 10-d-old rats. Experimental protocol and designations as described in Figure $1 A$; the autoradiogram is composed from the same experiment. $B$, Densitometric analysis represents data from two separate experiments. Results ( $n=8$ /group) are expressed as mean \pm SEM. $p \leq 0.05$ versus respective saline $(\mathrm{Sal})\left({ }^{*}\right)$ or control PRL $(\dagger)$ group. lactating mothers until they were $25 \mathrm{~d}$ old. Two hours after MS, pups were injected with PRL. No food or water was provided, replicating the same conditions used with the 10-d-old rats. As illustrated in Figure 6, PRL enhanced the expression of $O D C(p<$ $0.002)$ and c-myc $(p<0.001)$ mRNAs overall, but no PRL $\times$ MS interaction was observed (two-way ANOVA; $O D C, p=0.56$; c-myc, $p=0.72$ ).

\section{DISCUSSION}

\section{MS-depressed $O D C$ induction in neonatal rats may be mediated by c-myc and max downregulation}

This study indicates that the decreased expression of the $O D C$ gene observed during short-term MS of preweanling rat pups may be mediated by the downregulation of the key protooncogenes c-myc and max. We found that the suppression of PRL-induced increase in $O D C$ mRNA by MS was accompanied by a concomitant decrease in c-myc and $\max$ mRNA levels. This direct correlation between c-myc and max mRNAs and $O D C$ mRNA expression also was observed during all of the stimulatory and inhibitory changes in $O D C$ transcription initiated by PRL or MS, respectively. Coincident with this finding is the demonstration by Bello-Fernandez et al. (1992, 1993) that constitutive c-myc expression suppresses cell-cycle arrest, en-

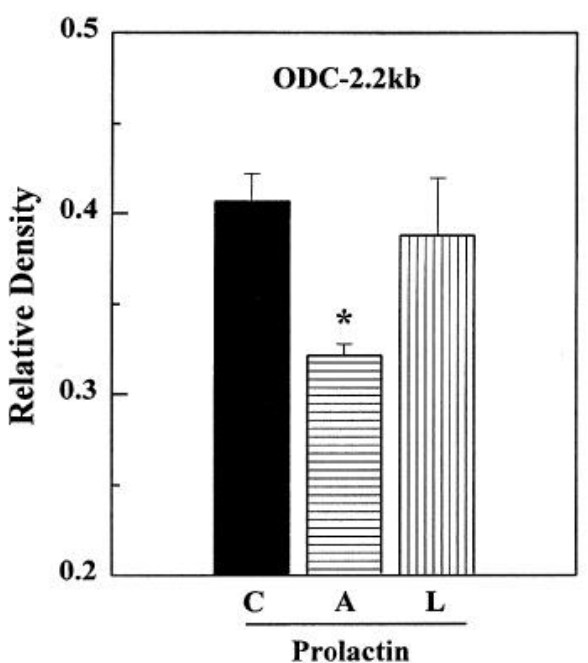

Figure 4. Effect of touch deprivation versus food deprivation on PRLinduced expression of $O D C 2.2 \mathrm{~kb}$ mRNA in 10-d-old rats. Pups were placed with control $(C)$, anesthetized $(A)$, or nipple-ligated $(L)$ dams. After $2 \mathrm{hr}$, all animals were injected with PRL and killed $2 \mathrm{hr}$ later. Results (mean \pm SEM) represent densitometric analysis $(n=8$ or 9$)$ of two separate experiments. ${ }^{*} p \leq 0.05$ versus control. 
Figure 5. Effect of touch deprivation $(A)$ versus food deprivation $(L)$ on PRL-induced expression of hepatic c-myc and max mRNAs in 10-d-old rats. Experimental protocol as described in Figure 4. Results (mean \pm SEM) represent densitometric analysis $(n=5-8)$ of two separate experiments. ${ }^{*} p$ $\leq 0.05$ versus respective control $(C)$ group.

hances entry into $S$ phase, and results in growth factorindependent expression of $O D C$. Moreover, by using murine $O D C$ promoter-X gene constructs, these investigators concluded that c-myc promotes cell-cycle progression because it is a potent transactivator of $O D C$ transcription. This concept is supported further by recent evidence that Myc and Max form a protein heterodimer that acts as a powerful transcriptional modulator of $O D C$ gene expression by binding to the CACGTG motif of the promoter region of the gene (Peña et al., 1993).

Similarly to Myc and Max, Fos-Jun protein heterodimers have been shown to modulate transcriptional activity by binding to regulatory AP-1 sites of target genes. These heterodimers can either stimulate or repress transcription, depending on which member of the Jun family complexes with the Fos protein (Ransone and Verma, 1990; Angel and Karin, 1991; Kerppola and Currant, 1991). Also, it has been reported that c-fos can activate transcription of the $O D C$ gene in $\mathrm{PC} 12$ cells directly by binding to cis-regulatory sequences that have been identified in the promoter region of the gene (Wrighton and Busslinger, 1993). Although it is possible that the small decline in c-fos mRNA levels caused by MS contributes to the marked decrease in $O D C$ gene expression, the lack of intraanimal correlation between observed decreases in c-fos and decreases in c-myc, max, and $O D C$ mRNA does not support this concept.

PRL-stimulated c-myc, max, and $O D C$ gene expression is depressed by maternal touch deprivation but not maternal milk deprivation

Previous studies in neonatal rats have demonstrated that the suppression of $O D C$ enzyme synthesis by MS is not related to changes in body temperature or nutritional factors, and that tactile stimulation in the form of stroking with a brush at a frequency that mimics maternal licking patterns reliably prevents or reverses all effects of MS on $O D C$ enzyme activity (Butler et al., 1978; Kuhn et al., 1979; Pauk et al., 1986). Similarly, the current results indicate that although the expression of c-myc, max, and $O D C$ is reduced significantly in pups left with an anesthetized lactating mother (pups suckle and feed but are not licked), such expression is not affected in pups placed with nipple-ligated lactating mothers (pups are touched and suckle but receive no food). These experiments clearly demonstrate that maternal touching, but not maternal milk, alters the expression of $O D C, \mathrm{c}-m y c$, and $\max$ mRNAs in young animals. This observation further implicates the proto-oncogenes c-myc and $\max$ in the signaltransduction pathway mediating the inhibition by MS of PRL induction of $O D C$ gene expression.
Figure 6. Effect of MS on $P R L$-induced expression of $O D C 2.2 \mathrm{~kb}$ and c-myc mRNAs in 25-d-old rats. Experimental protocol and designations are as described for 10-d-old pups in Figure 1A. Results (mean \pm SEM) represent densitometric analysis $(n=3$ or 4). ${ }^{*} p \leq 0.05$ versus respective saline ( $\mathrm{Sal}$ ) group.

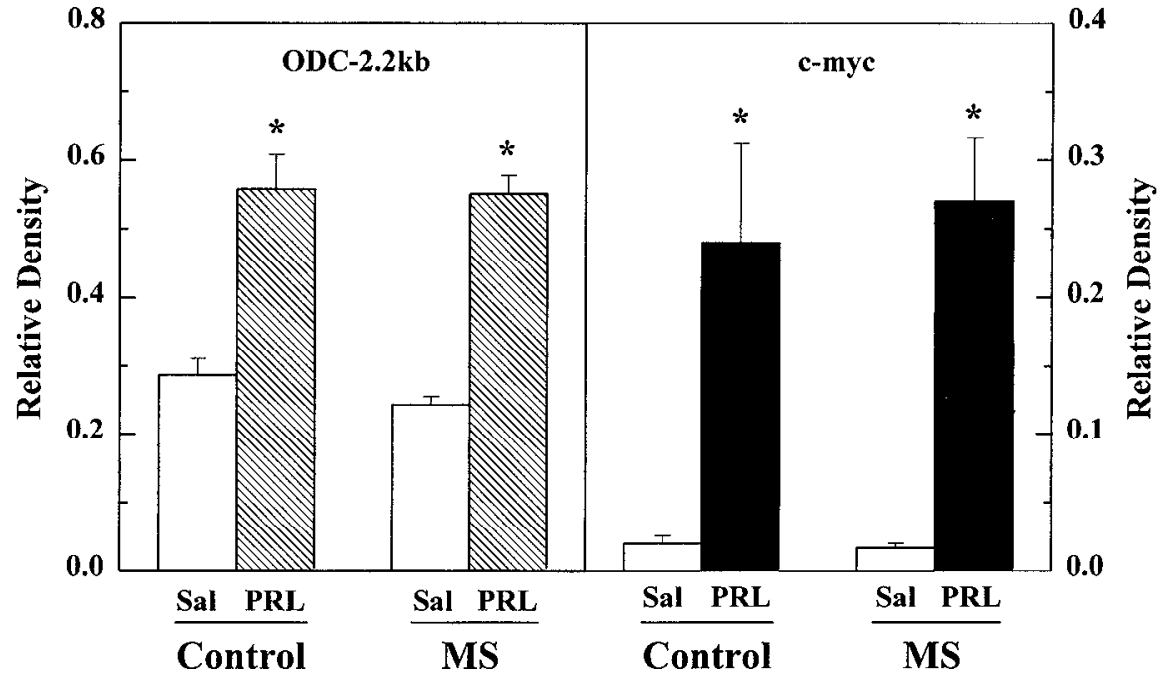




\section{MS-induced suppression of c-myc and $O D C$ gene expression is age-dependent, occurring only in preweanling-age pups}

The effect of maternal tactile stimulation on the regulation of $O D C$ enzyme activity and DNA synthesis in the neonate is age-dependent, i.e., the influence of maternal touching on $O D C$ activity occurs only before $18-20 \mathrm{~d}$ of the postnatal period but not at $25 \mathrm{~d}$ of age or later (Butler et al., 1977, 1978; Bartolome et al., 1986, 1991). The present results show that the effect of MS on the expression of $c-m y c$ and $O D C$ mRNAs follows the exact pattern observed with $O D C$ enzyme activity in that it is only downregulated during the preweanling developmental period.

\section{CONCLUSIONS}

This study shows that PRL markedly stimulates the expression of the IEGs c-myc and max and the $O D C$ gene in maternally touched neonatal rat pups, but not in pups deprived of maternal tactile stimulation. These results are consistent with the following hypotheses: (1) induction of $O D C \mathrm{mRNA}$ by growthpromoting hormones in vivo is regulated at least in part by the proto-oncogenes c-myc and max, the protein products of which are known to act as transcriptional activators of the $O D C$ genc; and (2) that downregulation of $\mathrm{c}-m y c$ and max is involved in the suppression of $O D C$ gene expression by maternal tactile, but not food, deprivation. Because we have demonstrated that supplementation of tactile stimulation to touch-deprived premature human infants markedly increases weight gain and neurobehavioral maturation (Field et al., 1986; Schanberg and Field, 1987; Scafidi ct al., 1990), it is clear that clucidating the subcellular mechanisms by which environmental input alters the expression of individual gene response to trophic hormones like PRL and GH during mammalian development is of great clinical import.

\section{REFERENCES}

Angel P, Karin M (1991) The rolc of Jun, Fos and the AP-I complex in cell proliferation and transformation. Biochim Biophys Acta 1072:129-157.

Bartolome IV, Bartolome MR, Dalner I A, Evans CJ, Barchas JD, Kuhn CM, Schanberg SM (1986) Effects of beta-endorphin on ornithino decarboxylase in tissues of developing rats: a potential role for this endogenous neuropeptide in the modulation of tissue growth. Life Sei $38: 2355-2362$.

Bartolome JV, Bartolome MB, Lorber BA, Schanberg SM (1991) CNS beta-endorphin regulation of insulin-induced ornithine decarboxylaso expression in liver of neonatal rats. Mol Cell Neurosci 2:1-5.

Bartolome JV, Wang S, Bartolome MB (1995) Transeription-dependent and -independent regulation of hepatic ornithine decarboxylase activity by CNS $\beta$-endorphin in rat pups. Mol Brain Res 33:149-156.

Bello-Fernandez C, Cleveland JL (1992) c-Myc transactivates the ornithine decarboxylase gene. Curr Top Microbiol Immunol $182: 445-452$.

Bello-Fernander, C, Packham G, Cleveland II (1993) The ornithine decarboxylase gene is a transcriptional target of c-Myc. Proc Natl Acad Sci USA $90: 7804-7808$.

Blackwood EM, Eisenman RN (1991) Max: a helix-loop-helix zipper protein that forms a sequence-specific DNA-binding complex with Myc. Science 257:1211-1217.

Badvo R (1990) Growth lactor responsive genes in fibroblasts. Cell Growth Differ 1:305-309.

Butler SR, Schanberg SM (1977) Effect of maternal deprivation on polyamine metabolism in pre-weanling rat brain and heart. Lile Sci 21:877-884.

Butler SR, Suskind MR, Schanberg SM (1978) Maternal behavior as a regulator of polyamine biosynthesis in brain and heart of the developing rat pup. Science 199:445-446.
Chomczynski P, Sacchi N (1987) Single-step method of RNA isolation by acid guanidium thiocyanate-phenol-chloroform extraction. Anal Biochen 162:156-159.

Colc MD (1986) The myc oncogene: its role in transformation and differentiation. Annu Rev Genet 20:361-384.

Crowe PD, Bucklcy AR, Zorn NE, Rui II (1991) Prolactin activates protein kinase $C$ and stimulates growth-related gene expression in rat liver. Mol Cell Endocrinol 79:29-35.

Curran T, Gordon MB, Rubino KL, Sambucetti LC (1987) Isolation and characterization of the c fos (rat) cDNA and analysis of posttranslational modification in vitro. Oncogene 2:79-84.

Evoniuk G, Kuhn C, Schanberg S (1979) The effect of tactile stimulation on serum growth hormone and tissue ornithine decarboxylase activity during maternal deprivation in rat pups. Conmun Psychopharmacol $3: 363-370$.

Field TM, Schanberg SM, Scafidi F, Bauer CR, Vega-Lahr N, Garcia R, Nystrom J, Kuhn CM (1986) Effect of tactilc/kinesthetic stimulation on preterm nconates. Pediatrics 77:654-658.

Frasier SD, Rallison ML (1972) Growth retardation and emotional deprivation: relative resistance to treatment with human growth hormone. J Pediatr Res 80:603-609.

Harlow HF, Zimmerman RR (1959) Affectional responses in the infant monkey. Science 130:421-432.

Heby $O$ (1981) Role of polyamines in the control of cell proliferation and differentiation. Differentiation 19:1-20.

Herschman HR (1989) Extracellular signals, transcriptional responses and cellular specificity. Trends Biochem Sci 14:455-458.

Hinde RA, Spencer-Booth Y (1971) Fffects of hrief separation from mother on rhesus monkeys. Science 173:111-118.

Hofer MA (1981) Toward a developmental basis for disease predisposition: the effects of early matcrnal separation on brain, bchavior and cardiovascular system. Assoc Res Nerv Mental Dis 57:209-228.

Kerppola TK, Curran T (1991) Transcription factor interactions: basics on zippers. Curr Opin Struct Biol 1:71-79.

Kuhn CM, Butler SR, Schanberg SM (1978) Selective depression of serum growth hormone during maternal deprivation in rat pups. Scicnce 201: 1034--1036

Kuhn CM, Evoniuk G, Schanberg SM (1979) Loss of tissue sensitivity to growth hormone during maternal deprivation in rats. Life Sci $25: 2089-2097$.

Lamph WW, Wamsley P, Corsi PS, Verma IM (1988) Induction of protooncogene jun/AP-1 by serum and TPA. Nature 334:629-631.

Land H, Parada LF, Wcinberg RA (1983) Tumorigenic conversion of primary embryo fibroblasts requires at least two cooperative oncogenes. Nature 304:596-602.

Lehrach II, Diamond D, Wozney JM, Boedtker H (1977) RNA molecular weight determinations by gel electrophoresis under denaturing conditions, a critical reexamination. Biochemistry 16:4743-4751.

Lincoln LW, Hill A, Wakerly JB (1973) The milk ejection reflex of the rat: intermiltent function is not abolished by surgical levels of anesthesia. J Endocrinol 57:459-476.

Lüscher B, Eisenman RN (1990) New light on Myc and Myb. Genes Dev $4: 2025-2035$.

Marton LJ, Morris DR (1987) Molecular and cellular function of the polyamines. In: Inhibition of polyamine biosynthesis: biological significance and basis for new therapies (McCann PP, Pegg AE, Sjoerdsma A eds), pp 79-105. New York: Academic.

Pauk J, Kuhn CM, Ficld TM, Schanberg SM (1986) Positive effects of tactile versus kinesthetic or vestibular stimulation on neuroendocrine and ODC activity in maternally-deprived rat pups. Life Sci $34: 2081-2087$

Peña A, Reddy CD, Wu S, Hickok NJ, Reddy EP, Yumet G, Soprano DR, Soprano KJ (1993) Regulation of human ornithine decarboxylase expression by the c-Myc/Max protein complex. J Biol Chem 268:27277-27285.

Powell GF, Brasel JA, Blizzard RM (1967) Emotional deprivation and growth retardation simulating idiopathic hypopituitarism. I. Evaluation of the syndrome. N Engl J Med 276:1271-1278.

Powell GF, Hopwood NJ, Barratt ES (1973) GH studics before and during catch-up growth in a child with cmotional deprivation and short stature. J Clin Endocrinol Metab 37:674-679.

Ransone LJ, Verma IM (1990) Nuclear protooncogenes fos and jun Annu Rev Cell Biol 6:539-557. 
Sabath DE, Broome HE, Prystowsky MB (1990) Glyceraldehyde-3phosphate dehydrogenase mRNA is a major interleukin-2-induced transcript in a cloned T-helper lymphocyte. Gene 91:185-191.

Scafidi FA, Ficld TM, Schanbcrg SM, Baucr CR, Tucci K, Robcrts J, Morrow C (1990) Massage stimulates growth in preterm infants: a replication. Infant Behav Dev 13:167-188.

Schanberg SM, Field TM (1987) Sensory deprivation stress and supplemental stimulation in the rat pup and preterm human neonate. Child Dev 58:1431-1447.

Schanberg SM, Kuhn CM (1980) Maternal deprivation: an animal model of psychosocial dwarfism. In: Enzymes and neurotransmitters in mental disease (Usdin E, Sourkes T, eds), pp 373-395. Chichester: Wiley.

Schanberg SM, Kuhn CM (1985) The biochemical effects of tactile deprivation in neonatal rats. Perspect Behav Med 2:133-148.

Schanberg SM, Evoniuk G, Kuhn CM (1984) Tactile and nutritional aspects of maternal care: specific regulators of neuroendocrine function and cellular development. Proc Soc Exp Biol Med 175:135-146.
Slotkin TA, Bartolome J (1986) Role of ornithine decarboxylase and the polyamines in nervous system development: a review. Brain Res Bull $17: 307-320$

Spencer CA, Groudine M (1991) Control of c-myc regulation in normal and neoplastic cells. Adv Cancer Res 56:1-48.

Wagner AJ, LeBeau MM, Diaz MO, Hay N (1992) Expression, regulation and chromosomal localization of the max gene. Proc Natl Acad Sci USA 89:3111-3115.

Wagner AJ, Meyers C, Laimins LA, I lay N (1993) c-Myc induccs the cxprcssion and activity of ornithine decarboxylase. Cell Growth Differ 4:879-883.

Wen L, Huang J-K, Blackshear PJ (1989) Rat ornithine decarboxylase gene nucleotide sequence, potential regulatory elements, and comparison to the mouse gene. J Biol Chem 264:9016-9021.

Wrighton C, Busslinger A (1993) Direct transcriptional stimulation of the ornithine decarboxylase gene by Fos in PC12 cells but not in fibroblasts. Mol Cell Biol 13:4657-4669. 